\title{
Canada-China Science and Technology Relations: An 80-Year History of Collaboration
}

\author{
Margaret McCuaig-Johnston* \\ China Institute, University of Alberta, Edmonton T6G 2R3, Canada \\ Institute for Science, Society \& Policy, University of Ottawa, Ottawa KIN 6N5, Canada \\ Duke Kunshan University, Kunshan 215316, China \\ Asia Pacific Foundation of Canada, Toronto M5G 2J5, Canada
}

\begin{abstract}
For eight decades, China and Canada have engaged in an increasingly rich and comprehensive collaboration in science, technology and innovation. Beginning with the personal engagement of some of the most prominent innovators in both countries in the 1930s through the 1970s, it was realized that China was building on millennia of leadership in innovation, while Canada was in the forefront of Western advances in key areas of research. As China began to open up to the West in the late 1970s, Canada's development agencies focused on helping China build capacity. University collaborations have also been strong, facilitated by the large Chinese diaspora in the Canadian research community. Canadian companies have had long-standing relations in China, and start-up incubators and accelerators in both countries have linkages with their counterparts. Over the years, Canadian and Chinese governments have deepened their S\&T engagement, with an Agreement for Science and Technology Collaboration signed in 2007, and the Canada-China Joint Committee on S\&T (CCJC) established to guide joint initiatives including a funded program for collaborative research. The most recent events were the inaugural meeting of the Sino-Canadian Innovation Dialogue held on October 29, 2018 and the CCJC meeting on October 30, 2018. The future is bright for continuing collaboration in the coming decades.
\end{abstract}

\section{Keywords}

science and technology; innovation; collaboration; development; universities; business; government.

\footnotetext{
* Corresponding author at: mmccuaig@uottawa.ca
} 


\section{Introduction: Eight Decades of Engagement and Collaboration}

It is widely known that, for millennia, China led the world in science and technology. Innovations such as paper, fireworks, silk, paper money, clocks, umbrellas, type printing, seismographs, porcelain, iron smelting and seed drills made their way over centuries to centres in the West where they were incorporated into Western society. China's leadership in science and technology was documented thoroughly for a Western audience by Cambridge University's Dr. Joseph Needham in his 21 volumes of Science and Civilisation in China (Needham, 1954). With the Reform and Opening announced by Deng Xiaoping in December 1978 the country's science and technology research and innovation were given top priority, and the government of President Xi Jinping has made innovation the key driver of the Chinese economy.

The relationships that develop between Chinese scientists and engineers and those in other nations are not like the rational transactional exchanges that are the norm with most other countries. Rather than "transactional", they are "relational", depending upon years of engagement and mutual trust. One knows the expression guanxi reflecting the importance of "connections and networks" in the work environment and personal lives of the Chinese. But that does not quite capture the xin or real "trust" necessary for good collaboration in the sphere of science and technology that is a requirement for engaging on S\&T or R\&D in China.

This paper covers Canada-China Science, Technology and Innovation (STI) relations over eight decades. It will look at the early xin that developed between Canadian and Chinese researchers, particularly during periods in China's history when the country really needed the help in medicine, agriculture and development aid that Canadians could provide. It will then go on to discuss the deepening of Canada/China academic, industry and government relationships in science, technology

and innovation over the years. The paper will conclude with reflections on the potential for future collaboration. As China emerges as a nation driven by innovation, it should be remembered that Canada played an important role in bringing it to this stage in its development. Going forward, it will be critical for Canada and China to cement a viable science and technology partnership for the mutual benefit of both. As with all dimensions of Canada's relationship with China, such a partnership requires time, effort and resources invested. It will also need a sustained and consistent focus on the long term objective of the collaborative advancement of science, technology and innovation in both countries.

\section{Building Science and Technology Capacity in China: The Early Years of Engagement and Development Assistance}

Through the decades following 1949, Canadians visiting China have been received with warmth and friendship. This stems in the first instance from the sacrifice of Canadian Doctor Norman Bethune. He had joined the Communist Party in 1936 to help in the Spanish Civil War where he organized the first mobile blood transfusion service. After returning to Canada to raise funds for Communist efforts, he left again in 1938 to help the Communists in the Shanxi-Hebei border region of China. Bethune is the first Canadian innovator to help the Communist Party of China's Eighth Route Army - his innovations of 12 medical and surgical instruments were put to work in the field, including the 'Bethune Pneumothorax Machine' and the Mobile Blood Transfusion Unit he invented in the Spanish Civil War, and he authored 
14 articles on thoracic techniques (Montreal Neurologic Institute and Hospital, 2017). He is credited with bringing modern medicine to rural China. Bethune died in 1939 from blood poisoning following an operation in the field. Generations of Chinese students were taught to revere Bái Qiúên, to recite Mao's eulogy of him, and to emulate his life of service (Snow, 1971; Endicott, 1980). At Canada/China events today, the name of Norman Bethune is still frequently mentioned as a representation of longstanding positive Canada/China relations. This is somewhat ironic given that Canadian governments of that era as well as our own time would not embrace Bethune's communist leanings.

Bethune's contributions to China were followed by those of the world renowned McGill neurologist Dr. Wilder Penfield. In 1938-39, Penfield had trained and mentored Dr. Zhao Yi-Cheng at McGill, treating him as part of the Penfield family. Dr. Zhao had returned to China to become the country's first neurosurgeon, being asked by the Communist Government to lead a neurological unit in Beijing which became the Tianjin Neurological Institute. In 1943, Dr. Penfield led a delegation for a two week visit to Chongqing, Chengdu and Kunming City, and on his return, he wrote a lengthy report to the National Research Council of Canada and the Canadian government. When next he and his wife visited China in 1962, the Government asked Dr. Zhao and his wife to host them for visits to labs, institutes and historical sites as well as at the National Day Celebration, and they had an extensive and friendly talk with Chairman Mao at Tiananmen. This was the first of many exchanges, and it led directly to an academic exchange program between McGill University and Peking University (Beida). Dr. Zhao is known as the founder of neurosurgery in China and trained more than 200 Chinese neurosurgeons (Montreal Neurological Institute and hospital, 2017).

In August of 1958, Professor Tuzo Wilson of the University of Toronto and a Council member of the National Research Council of Canada (NRC) from 1958 to 1964 attended a meeting of scientists from sixty-six countries in Moscow for the planning of the International Geophysical Year. He decided to return home via the Trans-Siberian railway and passed a one month tour throughout China hosted in each city by the Chinese Academy of Sciences (CAS), visiting geophysical institutes and universities as well as important regions vulnerable to earthquakes. It was the first visit of the NRC to China since 1949. Dr. Wilson wrote a book about his very positive impressions of his month in China (Wilson, 1959), and went on to become President of the Royal Society of Canada, President of the American Geophysical Union, a member of the Science Council of Canada, and the first Director General of the Ontario Science Centre where in 1982 he organised an exhibition of Chinese scientific artefacts representing innovations in China over 7,000 years. ${ }^{1}$ The display was said at the time to be "the most spectacular exhibition of ancient Chinese science and technology ever assembled outside China", and after worldwide study, the Ontario Science Centre was chosen as the model for the Beijing Science Centre (Bradshaw, 1982). The collaborations that Dr. Wilson began in geoscience continue to this day in the close relationships between scientists in this field of great importance to both Canada and China. In his early years Dr. Wilson had worked for the Geological Survey of Canada (GSC) that is now part of the Lands and Minerals Sector of Natural Resources Canada (NRC). The GSC has had extensive relations in China in the years since Dr. Wilson first visited the country, particularly in the area of

\footnotetext{
${ }^{1}$ China Science and Technology Palace Preparatory Committee and the Ontario Science Centre, China - 7000 Years of Discovery, Toronto: Ashton Potter Ltd, 1982.
} 
earthquake and landslide research which is of such importance in China. ${ }^{2}$

In the early 1960s, at a time of great hunger and poverty in China, the government of Prime Minister John Diefenbaker provided much needed Canadian grain. ${ }^{3}$ In 1970, the government of Prime Minister Pierre Trudeau was one of the first Western Bloc countries to recognize the People's Republic of China, behind only the UK and France. This stemmed at least in part from the fact that Trudeau himself visited China in 1960, travelling throughout the countryside during the Great Leap Forward and writing a book about his impressions of a China that few Westerners understood in those early days (Trudeau and Hebert, 1961). In 1971, Canada voted in favour of the People's Republic of China taking its seat in the United Nations, and in 1973, Prime Minister Trudeau made an official visit to China. While these events do not relate directly to research and development, they were very important elements in the developing mutual respect, collaboration and trust between our two countries. They provided a foundation of positive goodwill that has lasted decades in the Chinese psyche. This in turn has been a good contributor to positive relations over the years in science and technology.

While the early years of S\&T collaboration were ad hoc and dependent upon warm bilateral collaborations between stellar scientists in both countries, beginning in the 1970s Canada-China relations were characterised by Canadian development projects in China that often had an R\&D dimension. They were designed to develop China's capacity, particularly in environment, resource and industry sectors. According to B. Michael Frolic, early discussions between the two countries took place between 1974 and 1979 in the areas of “... geology, oceanography, remote sensing, metallurgy, coal mining, railways, ports, agriculture, forestry and fisheries. PRC missions came to Canada and learned about Canadian technology and often made commercial contracts at the same time" (Frolic, 1966). Very soon, development assistance through S\&T as well as related governance advice were being offered through two of Canada's development agencies, the International Development Research Centre and the Canadian International Development Agency. Both were active in China for decades, usually in complementary roles.

The International Development Research Centre (IDRC) is a Crown corporation charged with helping developing countries to apply new knowledge to the economic and social improvement of their societies. It identifies and analyses emerging challenges in the given country using its own staff of senior researchers and program officers and its international network of experts, and funds researchers in the country being assessed. These teams work with leaders at national, provincial, and local levels to analyse the issues, develop pilot or experimental initiatives, document the options and recommendations, and assist with implementation plans. IDRC has worked in China for thirty-six years and is among the world's top ten funders of development research. ${ }^{4}$ In fact, in 1979, an IDRC project was Canada's first personnel exchange involving technology transfer to China, and indeed this was the first formal entry by any country into a bilateral development assistance relationship with China (Wilson, 2001). In China,

\footnotetext{
${ }^{2}$ To name just a few examples, in 2013, NRCan signed an MOU with the China Earthquake Administration and undertook two project agreements with the China Geological Survey, renewing its MOU with CGS in May 2017 in Ottawa. In addition, a broader MOU regarding Cooperation in Lands and Minerals was signed by Minister of Natural Resources Jim Carr in June 2017. This is in addition to NRCan's continuing cooperation in earth observation technologies with the CAS Institute for Remote Sensing and Digital Earth. Dr. Wilson would be delighted with the deepening of the activities that he initiated.

${ }^{3}$ For more details see www.collectionscanada.gc.ca/2/4/h4-3331-e.html

${ }^{4}$ IDRC, Canada's International Development Research Centre: Briefing Notes, p.1.
} 
IDRC has worked across all program lines (agriculture; water and environment; global health policy (e.g. infectious disease response practices); science and innovation and social and economic policy) to identify solutions and link Chinese institutions with their Canadian counterparts.

While its work has provided many practical sectoral solutions, it has also taken a broader view of China's science and technology challenges and opportunities. From time to time, IDRC has taken a step back to assess, with Chinese partners, the country's overall performance in science and technology policy. Such a project begun in 1995 under the leadership of the U.K.'s.

Dr. Geoffrey Oldham, reported in 1997 to Zhu Lilan, Member of the State Council Leading Group on Science and Technology, and Executive Vice-Minister of the then State Science and Technology Commission. This analysis identified, for example, the benefits of China's participation in big science projects and the need for a more explicit policy for international collaboration, while noting positively the flexibility of its approach for experimentation with approaches appropriate to different conditions. The Government of China's response to the report indicated that a new international S\&T collaboration strategy was being formulated that would: strengthen the links between S\&T collaboration and trade; increase cooperation on industrial and advanced manufacturing technologies; assist R\&D institutions to establish branches overseas; create a national fund for international S\&T cooperation; and explore channels for China's participation in big science projects.

IDRC went on in 1997 to initiate a major project on the Chinese National Strategy for International Science and Technology Cooperation which analysed past experiences of China's international S\&T collaboration, identified costs and benefits, brought together external and domestic experts, and reviewed the experience of other countries. As part of this process, China's Ministry of Science and Technology (MOST) convened national workshops, commissioned case studies and issue papers, and convened an international workshop to review the findings. The project was completed in 2001, and concluded that to date China had been a "modest contributor to major international S\&T debates and was on the sidelines of most international fora in which these debates occur". It recommended more direct engagement in big science, and a strategic orientation of China's international assistance for other developing countries. MOST followed up in each of these areas, and in a broader 2007 study of "Emerging Donors in International Development Assistance", IDRC documented the growth of China's substantive contributions to development assistance generally, and research for development more specifically. Interestingly, this report notes that all of China's bilateral aid is tied aid including research and development assistance grants and technical assistance (Chin and Frolic, 2007). On the other hand, an IDRC Report in 2000 entitled An Assessment of Twenty Years of Research Collaboration between China and the IDRC highlighted the fact that IDRC's aid was intended to benefit China rather than Canada, and that this was greatly appreciated by the Chinese recipients (Zhan and Oldham, 2000), though IDRC managers and scientists point out that Canada too has benefitted greatly from its projects in China over the years. ${ }^{5}$ Other benefits of IDRC's work in China identified in this report included project management skills as a best practice, introducing Chinese research teams to regional and global networks, valuable networking among research groups within China, and training opportunities among others. At the same time, the report identified opportunities for improvement

\footnotetext{
${ }^{5}$ Interview with Dr. Stephen McGurk, Vice-President Programs, International Development Research Centre, September 7, 2014.
} 
in IDRC's processes in China including longer visits in the field, shorter response time for project proposals, and longer project cycles (Zhan and Oldham, 2000).

These reports are a few of the broader S\&T policy-related IDRC analyses over the years; its sectoral, social science and other focussed reports have similarly helped China to develop and enrich its R\&D capacity and performance. IDRC's Vice President Dr. Stephen McGurk, for example, has spent more than 30 years studying Asia's rural development and developing with Chinese counterparts the country's rattan and bamboo industry and capacity, among other sectors. From October 30th to 31st in 2016, the delegation of the International Center for Bamboo and Rattan of the State Forestry Administration of China, led by the Co-Chair of its Board, Madam Jiang Zehui, Vice-Chair of the Subcommittee of Human Resources and Environment of the Chinese People's Political Consultative Conference met with Canadian officials including Dr. McGurk. ${ }^{6}$

However, IDRC's success does not rest as much on the reports it has produced as on the collaborative and iterative process that it employs in China, working with those who will benefit from its insights and proposals, so that they will be in a position to take action. And IDRC continues to work on a broad range of initiatives in China including reducing the impacts of climate change on water and agriculture sectors, as well as emerging and re-emerging infectious disease and eco-health - projects which are of high priority in Canada's government to government S\&T relations with China which will be discussed below.

The Canadian International Development Agency (CIDA) too played a very important role in China over the decades. Starting in 1981, CIDA (now merged into Global Affairs Canada (GAC)) provided substantive and significant development assistance in China that frequently had research, science or technology dimensions. ${ }^{7}$ While GAC no longer maintains a development assistance program in China, CIDA's past role in China is significant and therefore merits discussion here.

The early strategy for CIDA's China Program was to invest scarce resources in human development assistance (e.g. training) and "technical assistance" in six sectors: education and training, agriculture, forestry, energy, transportation, and telecommunications (Wilson, 2001). Each of these had a significant S\&T and/or R\&D dimension. One initiative in particular had a lasting effect: that is CIDA's role in establishing the China Council for International Cooperation on Environment and Development (CCICED), mentioned above. Many projects were undertaken in the 1980s, but the events in 1989 resulted in the Canadian Government cancelling or postponing many projects, including some which affected the S\&T connections at that time. Among the cancelled projects were the Lanzhou Lubricating Oil Evaluation Centre $(\$ 2.23 \mathrm{M})$ and the Urban Traffic Management Project $(\$ 4.82 \mathrm{M})$. Postponed projects included Oil and Gas Technology Transfer, Tanggua Animal Quarantine Upgrading, Comprehensive Transport Management, and Guangzhou Air Traffic Control (Wilson, 2001).

In the 1990s and 2000s, CIDA used other Canadian government agencies in addition to its own agency staff to deliver projects with China. For example, the Hebei Dryland Project $(\$ 4.9 \mathrm{M})$ was

\footnotetext{
${ }^{6}$ Chinese Embassy, Ottawa, November 3, 2016. http:/ca.china-embassy.org/eng/sgxw/t1412402.htm

${ }^{7}$ CIDA was merged with the Department of Foreign Affairs and International Trade in 2014, and is now part of the new Global Affairs Canada. It will be interesting to see how the development role evolves within this new organisation. It is hoped that there will be more coordination and synergy among the functions of the new department, while retaining the integrity of the very important development role that CIDA played for many decades.
} 
implemented by Agriculture and Agri-Food Canada as it provided the advantage of agriculture science specialists in the field, so to speak, resulting in direct technology transfer. Research included development and selection of drought-tolerant cultivars and preparation of more scientifically-based soil and water resource plans; Hebei Academy of Agriculture and Forestry Science was the university/ college partner. Two five year (2003-2008) CIDA projects relating to "small farmers" and sustainable agriculture had enormous impacts by training 42,940 Chinese participants in 615 capacity building training programs, 36 in Canada. Food safety was a major impact of the first, winning the prestigious Sannong Award in 2008, while the second transferred sustainable agriculture technologies through trained extension workers, among other impacts. ${ }^{8}$ Another CIDA science-related agriculture project related to improved potato production where one outcome was the development of a potato that had previously only been usable for starch become a table potato used at the Beijing Olympics, based on Canadian expertise and technology transfer.

One Agriculture Canada initiative that stands out as having huge impact in China is that of Dr. Vern Burrows who, in the 1990s, was a Canadian government scientist specializing in oats research. He knew of a Canadian series of hearty oats that could grow almost anywhere, and he worked with Chinese scientists on oat production in Jilin province, mixing thirty varieties of Canadian oats with local Chinese oats. His research found that when eight Canadian varieties were blended with Chinese oats, a much heartier local variety could be produced that vastly increased the production of oats in China - most importantly in regions where successful agriculture had previously been thought to be impossible (Wang, 2013). Dr. Burrows' research also brought benefits back to Canada in new strains of oats. In China he was honoured with the Friendship Award of China in 2003, and despite China's practice of not erecting monuments to people who are still living, a bronze bust of Dr. Burrows was unveiled in 2012 at the Baicheng Academy of Agricultural Sciences. Dr. Ren Changzhong, President of the Academy and a former student of Dr. Burrows declared at the ceremony that Dr. Burrows is "revered by the Chinese people and praised as an international friend in the style of Canada's Dr. Norman Bethune". Have we heard that name before? And back home in Canada, Dr. Burrows was awarded the "Agcellence Award in Innovation" in 2000 and the Order of Canada in 2001 - the highest honour awarded to Canadian citizens. Since then, Agriculture Canada and its ministry partners in China have established six joint agricultural science and innovation centres across China, with the support of universities and industries in both countries. ${ }^{10}$ Indeed, Dr. Burrows is now catching up to Dr. Bethune as the most frequently mentioned Canadian contributor to China's research and development, especially by the Chinese in their frequent and heartfelt toasts.

In the development of China's policy capacity in environmental science and climate change Canadians have made important contributions to the work of the China Council for International Cooperation on Environment and Development (CCICED) which reports to Premier Li Keqiang who

\footnotetext{
${ }^{8}$ Agriculture and Agri-Food Canada, Small Farmers Adapting to Global Markets Project: Final Report Ottawa: AAFC - CIDA China Project \#A-031565 April 30, 2009; Sustainable Agricultural Development Project: Final Report Ottawa: AAFC- CIDA China Project: A-032079 April 30, 2009.

${ }_{9}^{9}$ Agriculture Canada Press Release, China Bestows Rare Honour on Canadian Agricultural Scientist, June 24, 2012.

${ }^{10}$ Agriculture Canada, The China-Canada Science and Innovation Platform Available at www.agr.gc.ca
} 
had previously been responsible for its work. One such Canadian was Dr. David Strangway, past President of the Canada Foundation of Innovation which provides billions of dollars in funding to university and hospital research infrastructure in Canada, past President of the University of British Columbia, and Founder of Quest University in British Columbia. With Feng Zhijun, Counsellor with China's State Council, Dr. Strangway co-chaired the Task Force on Innovation and Environmentallyfriendly Society of the CCICED. In 2008, their report Building an Environmentally-friendly Society through Innovation: Challenges and Choices - A National Environmental Action Plan was submitted to China's State Council and then to Premier Wen Jiabao at a time when China was poised to act on a range of decisions to reduce pollution, increase energy efficiency, and enhance the roles of its R\&D institutions to contribute to innovation in China. ${ }^{11}$ This is extraordinarily important work, and the late Dr. Strangway made a significant contribution, as have other Canadians including Elizabeth Dowdeswell, co-chair of CCICED's Task Force on Environment and Social Development in 201213. Ms. Dowdeswell is Past President of the Council of Canadian Academies, and former Under Secretary General of the United Nations, and her appointment to the position of Lieutenant Governor of the Province of Ontario was announced in July 2014. As we now know, China has become an international leader in the Paris Climate Agreement and has made great strides in renewable energy and environmental science - and Canadians played an important role in helping to develop China's policy capacity to that end.

Through the years, CIDA and IDRC sometimes played complementary roles. For example, IDRC supported some of the task forces of CCICED that CIDA had helped China to create. Similarly, IDRC created and nurtured in-house the International Network of Bamboo and Ratan and devolved INBAR in the late 1990s to become the first and still only international research intergovernmental organisation based in China, and CIDA provided support to INBAR some years after this devolution. ${ }^{12}$ The last CIDA projects in China were completed in March 2014, as China was no longer a "developing country".

\section{Deepening the Academic Research Relationship}

As China STI experts Denis Simon and Cong Cao have observed, as an emerging global technological power, China will have to rely on "the sustained development, deployment and mobilization of a high-quality, high-performance cohort of scientists, engineers, and R\&D professionals who can position China at the cutting edge of global innovation and scientific advance" (Simon and Cao, 2009). Domestic industry is already demanding job-ready, innovative skills as was seen in a 2012 Canada/China Academic Forum panel of executives of three Chinese aerospace companies who described the following as the skill-sets they are looking for: systematic thinking; bold in innovation; up to date knowledge (ability, speed, transformation); summarizing and refining; thorough grasp of technology; interpersonal communications; responsibility awareness; team collaboration (mutual support, inclusion); focussed and hard-working; rigorous, careful and solid - zero tolerance for

\footnotetext{
${ }^{11}$ Report of the CCICED Task Force on Innovation and Environmentally-friendly Society, Building an Environmentally- friendly Society through Innovation 2008.11.12-14.

${ }^{12}$ Interview with Dr. Stephen McGurk, September 7, 2014.
} 
errors and mistakes. ${ }^{13}$ When challenged on this last point in expecting innovation but no mistakes, the executive clarified that these would be mistakes of the negligence variety rather than related to innovation in processes or products. But clearly, there is an expectation that the Chinese graduates of the future will have to have all or most of these skills - a tall order in any society's industrial system. One way to acquire those skills is to train in other cultural systems at universities, colleges and institutes of technology around the world, and China has had this strategy for decades. In addition, many academic programs in Western countries have co-op programs where students can get industrial experience along with their degree.

Since 1972, Canada has had student exchanges with China - primarily Chinese university students coming to Canada. In 1974, the Canada/China Scholars' Exchange Program was started by IDRC and the Social Sciences and Humanities Research Council (SSHRC). The Canada-China University Linkage Program was launched in the 1980s supporting 31 institutions that wished to work together. In the 1990s, CIDA created the Special University Linkage Consolidation Program supporting 11 linkage projects involving 25 Canadian and more than 200 Chinese universities, teaching hospitals and agencies. CIDA invested over \$250 million in higher education in China since the earlier 1980s (Zha, 2012). There are now more than 100,000 students coming to Canada from China each year, but fewer than 5,000 Canadian students going to China for study. ${ }^{14}$ This is an imbalance that the government of Canada and Canadian universities are endeavouring to address.

There have also been many exchanges of professors in all disciplines over the decades. This has resulted in a very close research relationship between the two countries which provides a significant platform for ongoing collaborations on science and technology. Several examples will illustrate the scope of the S\&T being developed by academic researchers in both countries working together:

- The University of Alberta and Tsinghua University (known as the MIT of China) have joined together to create the new Joint Research Centre for Future Energy and Environment for collaboration on energy, environment, climate change, renewable energy, advanced power systems, and energy transportation. ${ }^{15}$

- The University of Ottawa and the CAS University Shanghai Institute of Materia Medica (SIMM) have established a Joint Research Centre on Systems and Personalized Pharmacology on the medicinal properties of plants and the potential for development of new medications for diseases such as Ebola, TB, and HIV. ${ }^{16}$

- The Ottawa-Shanghai Joint School of Medicine is the first Sino-Canadian medical school as a collaboration of the University of Ottawa and Jiao Tong University. ${ }^{17}$

- The University of British Columbia has partnered with Chongqing Medical University in

\footnotetext{
${ }^{13}$ Author's notes from the Canada-China Academic Forum in Chengdu, August 3-5, 2012. The executives represented the aerospace companies AVIC, COMAC, and CASC.

${ }^{14}$ Speech by Ambassador Luo, Chinese Embassy, June 17, 2014. The numbers break down approximately twenty to one, Chinese students going to Canada vs Canadian students going to China.

${ }^{15}$ A UofA / Tsinghua Centre description is available at: https://www.ualberta.ca/news-and-events/mediarelations/news-releases2017-current/2017/april/chinese-partnerships-bolster-energy-and-environment-research-economic-diversification

${ }^{16}$ A UofO / CASU SIMM Centre description is available at: https://media.uottawa.ca/news/uottawa-and-chinese-academysciences-launch-innovative-research-centre

${ }^{17}$ International Research Branch, University of Ottawa, The University of Ottawa: A Proud Partner of China, p. 7.
} 
establishing the Canada/China Joint Centre for Translational Medical Research in Child Development and Alzheimer's Disease for which Canada Research Chair Dr. Song Weihong received China's highest honour for foreign experts - the Friendship Award. ${ }^{18}$

With each centre, there is a significant training element to educate students from both countries.

In addition, the enormous 1.52 million Chinese diaspora and Canadians of Chinese descent (of a total population of 35 million), including thousands of academic, government and industry researchers, as well as the extensive network of students will be a key advantage for Canada in deepening its collaborations with China. Indeed, in 2012 in the natural sciences and engineering (NSE) disciplines, in the flagship Discovery Grants of NSERC at \$394 million per year, the top five most common names were all Chinese: 50 Chen's, 49 Wang's, 47 Li's, 43 Zhang's, and 36 Liu's. The most common Anglo-Saxon name was Smith, trailing at 30. This demonstrates clearly that Chinese researchers and students coming to Canada will very often find Mandarin speaking colleagues on their research team, making the cultural interaction much easier.

The number of bilateral collaborations in NSE has exploded since 1996.

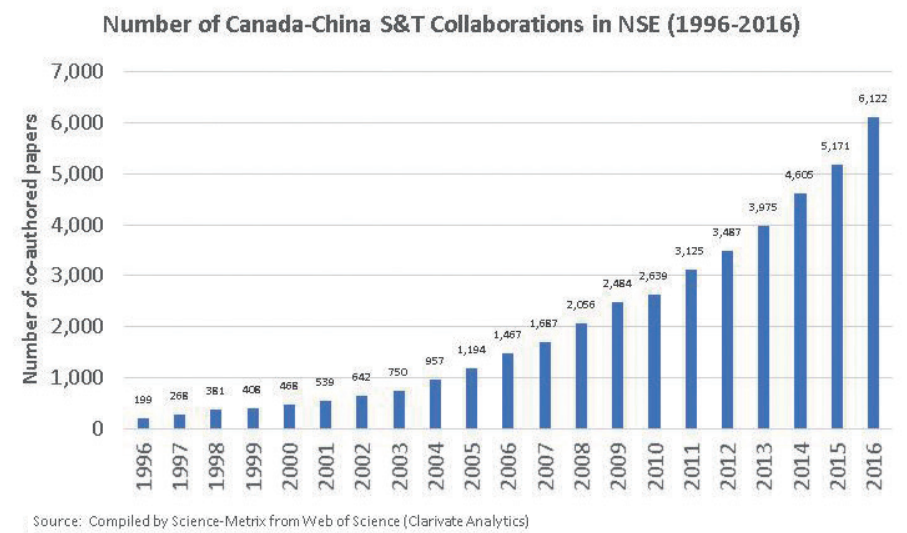

Fig. 1 Number of Canada-China S\&T collaborations in Natural Sciences and Engineering

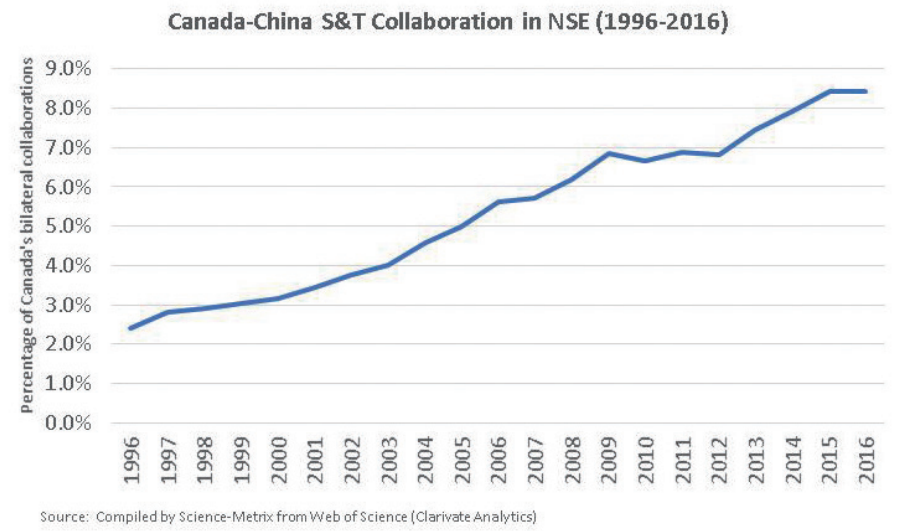

Fig. 2 Collaboration with China as a percentage of Canada's bilateral collaborations

\footnotetext{
${ }^{18}$ More information on the UBC/Chongqing initiative is available at: http://ubcapro.hk/2011/11/03/weihong-song-receiveschinas-top-honour-for-foreign-experts/
} 
Even as a percentage of Canada's overall bilateral collaborations, there is no question that China is now one of Canada's prime partners in research and development.

In Canada, education is provincial jurisdiction and consequently there is no national education department with leadership to undertake international strategies for collaboration with researchers in other countries. However, a number of proactive initiatives are fulfilling that function at least in part. Global Affairs Canada has engaged proactively on international education, having commissioned an independent panel to advise the government on Canada's International Education Strategy ${ }^{19}$ as well as its continuing role with China on collaboration on innovation. In addition, Canadian universities themselves have collectively organized to engage with China. The Canada/China Academic Forum met in Edmonton in 2010, Chengdu in 2012, and then in 2014 held a substantive workshop in Harbin to identify best practices and strategies for Dual Degrees at the doctoral level. The Forum included 27 Canadian and 40 Chinese universities with support from the China Scholarship Council, and these fora have proven very productive in developing new partnerships and identifying mechanisms that will allow both countries to deepen their research efforts and provide an enriched training experiences for students. An even larger group of Canadian universities and colleges was scheduled to travel to China in October 2017 to advance Canada-China academic relations, organized by UniversitiesCanada, but this mission was postponed two weeks before departure due to overlap with China's 19th Party Congress and it is hoped to reschedule to a later date pending information from Chinese partners. At the core of this delegation is the U15, Canada's top 15 research universities.

Canadian colleges too are working closely with China's institutes of technology for whom they have developed and implemented a leadership training program, and with whom they are initiating collaborative research. ${ }^{20}$ And a Canadian organisation called Mitacs is building on its role in offering Globalink research scholarships in China, as well as funding students in Canadian universities to participate in research projects in companies in China. ${ }^{21}$ The networks of researchers established through these initiatives will lead directly to joint Sino-Canadian innovations, and in the longer term will provide an expanding network for enriched collaborations in and between both countries.

The federal granting councils have been very active in funding international projects, for example through the G-8 and the Belmont Forum. And the three councils are funding more and more projects which include partners in China. In 2012, statistics were compiled for the first time across all three granting councils for a keynote presentation by the author at the Chengdu Canada-China Academic Forum. Below are the levels of funding from 2007 to 2012 for each of: the Natural Sciences and Engineering Research Council (NSERC), the Social Sciences and Humanities Research Council (SSHRC), and the Canadian Institutes for Health Research (CIHR), tabulating the dollar figures for all the councils-funded research projects involving at least one partner in China (McCuaig-Johnston, 2012). While the numbers are now somewhat dated, it is important to note that both the Canadians and Chinese at the Chengdu Forum were surprised and pleased that there was already so much bilateral collaboration taking place.

\footnotetext{
${ }^{19}$ Advisory Panel on Canada's International Education Strategy, International Education: A Key Driver of Canada's Future Prosperity: Final Report, Ottawa, August 2012. Available at http://www.international.gc.ca/education/report-rapport/strategy-stragtegie/index.aspx

${ }^{20}$ See information on the China programs of Colleges and Institutes Canada (formerly the Association of Canadian Community Colleges) at www.collegesinstitutes.ca/what-we-do/ Executive Leadership Development-China.

${ }^{21}$ Information on Mitacs Globalink research initiatives is available at www.mitacs.ca
} 

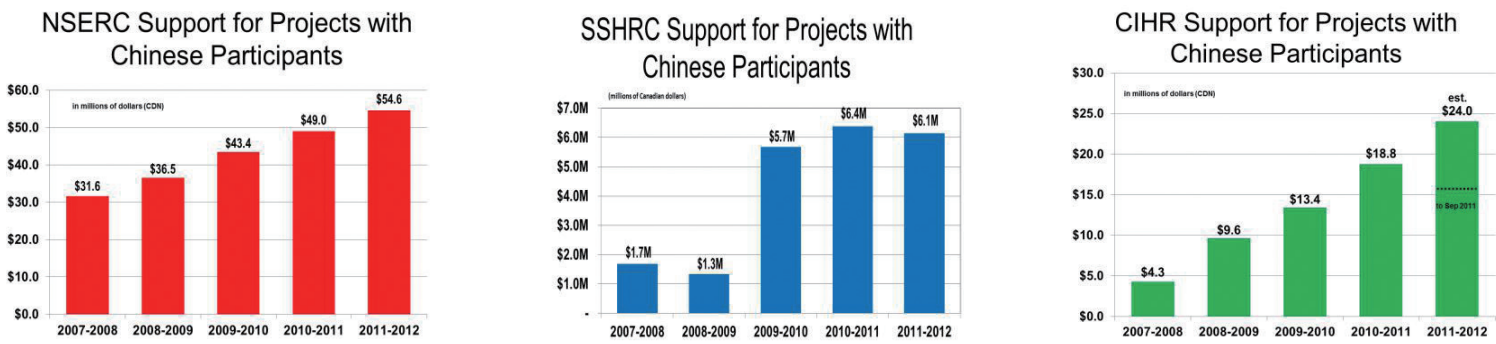

Fig. 3 Support for projects with Chinese participants in Natural Science and Engineering, Social Sciences and Humanities, and Health Research

In addition, the Conference Board of Canada has launched a five year national Post-Secondary Education and Skills Initiative which will identify and initiate new ways that a cross-Canada strategy can benefit the private sector in its need for employees who meet international standards of excellence and are networked globally. And it will identify ways in which universities can offer students opportunities to develop these skills. The key leaders of the Board's initiative have active networks with China's government and academic organisations, and China is very much in its sights as a priority for such international training, networking and benchmarking. ${ }^{22}$

In the past three years, China has invested massive amounts of funding to install world class research facilities across the country. University labs have been the big beneficiaries of this investment, along with the Chinese Academy of Sciences. Canadian researchers should start to look at labs and facilities in China as a new venue for their research projects. For example, the Canadian Light Source (CLS) synchrotron has 19 beamlines with potential for 10 more - the Shanghai Synchrotron has 60 with potential for more. ${ }^{23}$ Similarly, the Sudbury Neutrino Observatory labs (SNOLAB) is $2 \mathrm{~km}$ underground - the new Jinping Observatory in Szechuan is $2.4 \mathrm{~km}$ underground. One can see the theme that China is going bigger, deeper and better than any Western country in the labs it is building and equipping. This is an opportunity for Canada to collaborate with China and take advantage of top of the line equipment for our scientists to use. Big science projects such of these are generally characterized by such cooperation, as can be seen by the assistance being provided to the Director of Jinping by the Executive Director of SNOLAB. The culture of collaboration runs through all Big Science projects whose aim is to advance the common cause of understanding the universe.

On the research policy front, Canada and China together took an important leadership role in 2014, co-chairing the Global Forum of Research Councils (GFRC) in Beijing at which 60 heads of research granting councils from around the world engaged in substantive policy discussion of international measures for facilitating international research, including open access for publications and supporting the next generation of researchers. Canada subsequently hosted the May 2017 meeting of the GFRC in Ottawa.

\footnotetext{
${ }^{22}$ Conference Board of Canada, Centre for Skills and Post-Secondary Education, Ottawa: Conference Board Publications, 2013. Available at http://www.conferenceboard.ca/spse/default.aspx

${ }^{23}$ Source re Canadian Light Source beamlines: http://www.lightsource.ca/beamlines.html Source re Shanghai Synchrotron beamlines: http://ssrf.sinap.ac.cn/english/3/Introduction.htm Both downloaded August 18, 2017.
} 


\section{Sino-Canadian Industry Relations in Technology Development}

While Canada has much technology of interest to China, particularly in the energy and bio-medical sectors, Canada's overall track record in business investment in R\&D and commercialisation is still lagging those of other countries. Indeed, in China's National Innovation Index, Canada barely figures for reference in China's comparisons with leading innovative nations. The Index notes that "... Canada, Finland, Spain and Greece have slowed in R\&D expenditure growth" and just a passing reference that China is ranked $14^{\text {th }}$ in innovation performance and is " $\ldots$ already higher than several developed countries such as Sweden, the Netherlands, Austria, Canada and Italy and far ahead of other developing countries". The U.S., Japan, Republic of Korea, Germany, France and Israel are among the countries against which China is benchmarking its own performance across many factors of innovation. As China continues with its plan to become the world's foremost economic superpower fuelled by innovation, there is more and more that Canada can learn from China. With its international technology companies, its investments in R\&D (with Gross Expenditure on RD/GDP rate at 2.02\% ${ }^{24}$ having passed Canada's GERD/GDP in 2011), and investment in its highly qualified personnel, China is becoming the nation with which many other countries want to partner.

A paper by Dr. Chen Yong, of the Department of Science and Technology of Zhejiang Province illustrates the assessment of Canada's innovation system by China's policy analysts. Dr. Chen reviewed the literature in Canada to conclude that Canada has strong fundamentals in innovation, high quality research, high levels of investment in R\&D and higher education, strong student performance in science and mathematics, success in attracting and retaining highly skilled workers, and innovation capacity distributed across the country. Key sectors such as energy, environment, life sciences, aerospace and automotive are strong. International collaboration with China and other countries, notably the US are also strong. However, Dr. Chen goes on to suggest that the innovative capacity of Canadian enterprises is still relatively weak, and cooperation between industry and academia is not as close as it should be. He also suggests that Canada lacks strong initiatives for encouraging enterprises to increase their investment so that industry will invest more in innovation. He concludes that China can learn from Canada in the evaluation of innovation development and policies, in areas to improve the innovation system, and in the commercialisation of innovative products, by focussing cooperation with Canada in the areas of energy, environment, life sciences, agriculture, ICT and aerospace (Chen, 2012). For someone on the other side of the planet, Dr. Chen has assessed Canada's track record in innovation fairly accurately.

One explanation for Canada's track record on business innovation is provided in a report of the Council of Canadian Academies which identified Canada's special relationship with the U.S. economy through the North America Free Trade Agreement as providing the protection from economic stresses and "small catastrophes" that can propel companies into a strategy of intense innovation. In the comfortable niche of Canadian businesses, “... Aggregate profitability ratios have matched or exceeded those of the United States. With little motivation to change a successful formula, many firms have settled into a 'low-innovation equilibrium' that has conditioned business habits and ambitions, and shaped the predominant business culture in Canada (Council of Canadian Academies, 2013)."

\footnotetext{
${ }^{24}$ Ibid, p. 2.
} 
With an economy so closely tied to that of the U.S., Canadian business and government leaders pay close attention when Sino-American relations in science and technology are under stress. Such has been the case in recent years around issues such as theft of intellectual property of U.S. technology as well as cyber-attacks and spying - concerns shared by some in Canada for Canadian technology as well. In particular, Congressional distrust of China has had direct impact through its "... prohibition on expenditure of funds by the Executive Branch on U.S.-China co-operation in space and in science more broadly, which denies the U.S. government a potential tool for reducing strategic distrust with China" (Lieberthal and Wang, 2012). Consequent omission of China from some scientific meetings in the U.S. is both restriction of access to that which others will have, as well as a loss of face for a nation rising the ranks in innovation, and it further impacts the relationship. This rough patch in relations between the U.S. and China has prompted serious concern north of the Canada/U.S. border. As a former Canadian Ambassador to China put it, "It is never a good thing for Canada when U.S. relations with China are poor; our companies can be directly affected, since they can be tied to the U.S. through legislation (for example through conditions of ITARs); we have to work closely with U.S. officials to understand ways in which Canadian business might be affected, and what we can do to minimize impacts on them." ${ }^{25}$

There is not sufficient space in this overview of Canada/China relations in science and technology to include the many industry-related technology collaborations over the years. Suffice to say, there have been decades of exchanges between companies in China and those in Canada since the launch of Reform and Opening in 1978. As already mentioned, agriculture has been a critical sector over the years for Canadian and Chinese companies, as well as biotechnology and ICT (particularly in the years before Nortel's demise). However, the subject of energy is so pivotal to both countries now that it merits particular, if brief, attention.

Over the ten years of the Harper Conservative government, Ministers were fond of saying that Canada is an energy superpower, as the second biggest producer of uranium in the world, third largest producer of hydroelectricity, the third-largest producer of natural gas, vast oil and gas reserves, and advanced nuclear technology. ${ }^{26}$ Under the current Liberal Government, Ministers have toned down the 'superpower' rhetoric and are putting more focus on clean energy technology. For example, the March 2017 Budget cited Canada's commitment under Mission Innovation to double the country's 2014-15 baseline expenditures of \$387M for clean energy and clean technology research, development and demonstration by 2020, with Budget 2017 investing inter alia in new green infrastructure and clean technology. ${ }^{27}$ China too is a leading producer of energy and to meet its own demand it needs what can be produced domestically and bring the balance as imports. And China has been making astounding investments in renewable and energy efficient technologies. In fact, in all subsectors of energy Canada and China have much in common and stand to benefit significantly through increased collaboration in technology development.

\footnotetext{
${ }^{25}$ Interview, November 28, 2013; “ITARs" refers to the U.S. International Traffic in Arms Regulations under the U.S. Department of State.

${ }^{26}$ One example is a speech made by the Minister of Natural Resources Joe Oliver, Canada and China: Strengthening our economic ties, Shanghai, November 9, 2011 Available at http:/ / www.nrcan.gc.ca/media-room/speeches/2011/3373?destination=node/3287

${ }^{27}$ Budget 2017: Building a Strong Middle Class Department of Finance, March 22, 2017, p. 96.
} 
Canadian companies have been in the China market primarily for the significant potential trade benefits, but when their technology is involved, China reaps benefits too. For example, in the 1990s, GE Hydro Canada of Lachine, Quebec won one of the large turbine equipment orders for the then-new Three Gorges Dam. In fact, GE was only one of six foreign companies that were awarded contracts for Three Gorges, giving China access to advanced technology from around the world.

Over the decades, Canadian companies opened up markets in China through the introduction of advanced technologies. Nortel was a major force in China until its unfortunate demise, helping the country leapfrog over landlines and telephone poles to provide cellphone service across the countryside. Since then, China has sought to extend the leapfrogging approach (or "frog leaping" we sometimes hear) across other technology sectors. Bombardier is another Canadian company that has introduced advanced technology into China - in both the highspeed rail and aircraft sectors. Bombardier has had direct sales as well as partnerships with Chinese companies. At the same time, however, it has stimulated China to advance its own corporations in these sectors, sometimes in competition with Bombardier. As an example, on May 11, 2017 it was announced that China's CRCC Corp ${ }^{28}$ had bid successfully for a contract in Montreal - Bombardier's front yard. They will be providing 24 double-decker train cars to Montreal's regional commuter-rail service for just $\$ 69 \mathrm{M}$ - far under the budgeted $\$ 103 \mathrm{M}$ (Vanderclippe and Praet, 2017). Such is the international trading environment for technology companies. Bombardier has three joint ventures with CRRC Corp and no doubt this contract has been a subject of discussion since it was announced.

With an eye to the combined challenges of urbanisation and the environment, energy conservation, energy efficiency and renewable energy technologies are taking on a high priority for China, and Canadian companies and research labs are very active with China. In renewable energy, the National Research Council in Canada is working with Jiangsu Aoxin New Energy Automobile Company to commercialize the technologies of Canadian companies for electric vehicles, recognizing Canada's leadership in fuel cell and battery technologies. ${ }^{29}$ Ballard Power Systems of Burnaby B.C. has had pilots and some sales in China for many years and sees potential markets for its buses and autos in the context of China's move into fuel-efficient vehicles, as well as other product lines. For example, Ballard ran fuel cell buses at the 2008 Olympics in Beijing. It now has joint ventures with Guangdong Nation Synergy Hydrogen Power Technology and Weichai Technologies for a factory for fuel cell systems (Penner, 2016). Similarly Conserval solar wall technology was used to build the Athletes' Centre at the Athletes' Village, and now that building serves as the kindergarten for the surrounding apartment complexes. And Conserval now has a joint venture with China's SunRain. For more than twenty-five years, Canadian companies in clean energy technologies such as solar energy and Super E energy efficient homes have been supported in their collaborations with Chinese companies by Natural Resources Canada's CanmetENERGY clean energy technology labs. And two Candu nuclear plants were built in Qinshan in the early 2000s, and hoping for more, Candu Energy Inc now has a joint venture with China National Nuclear Corporation (CNNC) to build the Advanced Fuel Candu Reactors in China as well as to sell it

\footnotetext{
${ }^{28}$ CCRC Corp uses an acronym as its full official name.

${ }^{29}$ National Research Council news release, National Research Council Partners with China's Aoxin New Energy Automobile Co. to Help Commercialize Canadian Technology, Vancouver, November 15, 2010.
} 
to third countries. All four of these joint ventures are majority Chinese ownership, with manufacturing performed in China. With the threat in 2007 of a shortage of uranium used as fuel in reactors, Atomic Energy of Canada Ltd and the Nuclear Power Institute of China signed an MOU for collaborative R\&D in nuclear technology (Jiang, 2010). With the publication of the 2017 Global Cleantech Innovation Index, other nations can see from Canada's \#4 ranking that our country is a top source of clean technology. ${ }^{30}$ China in particular will take notice, as cleantech is one of its top priorities as it struggles to get on top of its environment and energy pressures.

In oil and gas, Canadian company Phase Separation Solutions has been very successful in offering advanced clean-up and treatment technologies for oil field waste and site remediation. In fewer than four years it established itself in China as a Canadian-Chinese company with an aggressive growth strategy. ${ }^{31}$ But the technology story in oil and gas goes far beyond trade and collaborative technology development opportunities into complex investments being made by China in Canadian companies, each carrying technology benefits. Starting in 2005, Chinese companies including State Owned Enterprises (SOEs) started buying blocks of shares in small and medium sized companies (16.69\% of MEG Energy by CNOOC and then $40 \%$ of Northern Lights Oil Sands by Sinopec), then buying the full value of small and medium sized companies (100\% of Nations Energy by CITIC Group), a large stake in the oilsands (Sinopec's \$4.65 billion purchase ConocoPhillips' 9.03\% stake in Syncrude's Oil Sands Project), culminating in CNOOC's purchase in June 2012 of Nexen for $\$ 15.1$ billion. This last went through the Government of Canada's investment review process successfully, but the Government subsequently brought in new guidelines indicating that SOEs in future will have the onus on them to demonstrate through a series of factors that the acquisition is of net benefit to Canada. ${ }^{32}$

With each of these purchases, China acquired important oil and gas technology, as well as the related expertise in how Canada manages large resource extraction facilities. While the drop in the price of oil has resulted in some losses by China for its massive investments in the Canadian oil patch, the long term intention of both countries is to seek out new markets in China for Canada's oil and gas resources. And one can see in the Canadian energy industry that there is a technology dimension in virtually every collaboration with China.

The government of Prime Minister Justin Trudeau has indicated it will provide for some degree of flexibility with SOE takeovers. In fact, it has recently approved several controversial investments including Anbang's takeover of Canadian retirement home chain Cedar Tree, ${ }^{33}$ Hytera Communications' takeover of satellite company Norsat, and O-Net Communications purchase of ITF Technologies without national security reviews. However, the sale of Canada's construction giant Aecon to Chinese interests was blocked in 2018 in order to protect national security.

Finally, Canadian and Chinese start-up companies - often the technology companies of the future - are beginning to find new linkages by way of incubators and accelerators in both countries.

\footnotetext{
${ }^{30}$ Government of Ontario, The world's leading cleantech innovations of the next decade are likely to emerge from Canada. Available at: https:/ / www.investinontario.com/spotlights/canadas-cleantech-sector-now-leads-g20

${ }^{31}$ For an overview of the company's entry and growth in China see http://phaseseparation.com/links/history.html

${ }^{32}$ The SOE Guidelines are available at http:/ / www.ic.gc.ca/eic/site/ica-lic.nsf/eng/lk00064.html\#p2

33 "Questions Over Chinese Purchases of Canadian Assets", The Strait Times, July 13, 2017. Available at: http://www.straitstimes. $\mathrm{com} /$ world/questions-over-chinese-purchases-of-canadian-assets
} 
Incubators in China are getting a strong influx of government funds to nurture start-ups, and they are increasingly partnering with incubators in the west, especially in Silicon Valley. In Canada, Invest Ottawa has a very strong partnership with Zhongguancun Development Group to nurture Canadian start-ups and introduce them to Chinese partners when they're ready, and companies from Velocity incubator in Waterloo have spent time at HAX accelerator in Shenzhen. Even makerspaces are finding synergies, with ARCHEloft in Calgary linking with SEEED in Shenzhen. More of these exchanges and partnerships can be expected in the coming years (McCuaig-Johnston and zhang, 2015a).

\section{Government to Government Relations in Science and Technology}

With the Reform and Opening policy announced by Deng Xiaoping in 1978, China started to open up to science and technology from the West. In 1979, on a cross-China tour of members of the University of Toronto Alumni, the author was pleased and impressed to see that the libraries of universities, colleges and teaching hospitals contained the latest science journals as the country made efforts to catch up to what had been happening in the rest of the world of science and technology.

Throughout the 1980s, 1990s and 2000s, the Government of China sent delegations to Ottawa and other regions of Canada to learn about Canadian programs and best practices in science and technology development. These delegations usually focussed on a particular area of science such as Agriculture or Geoscience, and Canadian officials, on behalf of their departments, sometimes entered into one to one memoranda of understanding (MOU) with their Chinese ministry counterpart in order to undertake ongoing collaboration. Examples of MOUs include:

- 1980 MOU between China's Ministers of Agriculture and State Farms and Land Reclamation, and Canada's Minister of Agriculture;

- 1986 MOU between the China Meteorological Administration and the Meteorological Service of Canada;

- 1993 MOU between Environment Canada and the State Environmental Protection Agency for, among other things, the transfer of technologies;

- 1994 MOU between the Chinese Academy of Sciences (CAS) Institute of Remote Sensing Applications and Natural Resources Canada's (NRCan) Centre for Remote Sensing;

- 1996 MOU between the National Natural Science Foundation of China and the Natural Sciences and Engineering Research Council of Canada (NSERC);

- 2001 MOU between the National Development Reform Commission of China and NRCan for cooperation in the field of energy;

- 2005 MOU between the Ministry of Water Resources and NRCan;

- 2007 MOU between China's State Oceanic Administration and Fisheries and Oceans Canada;

- 2012 umbrella MOU between CAS and NRCan in clean energy, earth sciences and mineral resources;

- 2014 MOU between the South China United Vaccine Institute and the Canadian Vaccine and Infectious Disease Organisation among others.

- 2015 MOU between the Chinese Ministry of Housing and Urban-Rural Development, the Canadian Forest Service, and the B.C. Ministry of Forests, Lands and Natural Resource Operations for Cooperation on Modern Wood Construction Technology. 
- 2016 Joint Declaration on Clean Technology Cooperation between the Minister of Innovation, Science and Economic Development and the Minister of Natural Resources with China's Vice Minister of the Ministry of Science and Technology.

These are just a few examples of many MOUs and agreements signed over the years with Chinese ministries and agencies with an intent of collaboration on S\&T among other objectives. These MOUs and others have been highly successful in deepening the relationships, and as they are normally five years in duration, some of those listed above have been renewed multiple times.

In addition to wanting to learn more about Canada's science and technology policies and programs, China was interested in learning about Canada's departmental governance and management techniques. Such was the case in 1998 when China's Minister of Water Resources proposed to house an Industry Canada executive in his Ministry for a two year period as a senior policy advisor to introduce team approaches to managing initiatives. Canada was not able to take up the offer, which was subsequently accepted by Craven Crowell, former Chairman of the Tennessee Valley Authority. But the Canadian government was open to a secondment to give Chinese officials direct experience in the management approach of a western government department. In 1999, Industry Canada hosted a one-year secondment of two mid-level officials of the Ministry of Water Resources to Industry Canada's Manufacturing and Processing Technologies Branch and Environmental Technologies Branch to learn about Canadian techniques of team management and how Canada was addressing industry sector technology challenges. ${ }^{34}$

Furthermore, requests came as early as the late 1970s from a number of countries including China's then State Science and Technology Commission (later to become the Ministry of Science and Technology) to sign a high level agreement with Canada on science and technology. As Richard P. Suttmeier observed in 1980, as China was making such overtures to a number of countries, "such cooperation would give China access to an expanded range of scientific and technical information, it could serve to set the pace or be the point of reference for Chinese research and development in certain fields, and it could ease the financial burden of an ambitious research and development program through cost-sharing arrangements" (Suttmeier, 1980). Canada's S\&T policy department at that time was the Ministry of State for Science and Technology (MOSST) which has since merged with other departments and agencies to become Industry Canada, and more recently Innovation, Science and Economic Development (ISED).

In 1982, the question of bilateral agreements in S\&T (government to government legally binding in international law) was referred to the Cabinet of Prime Minister Pierre Trudeau. The ministerial view was that the government already had general agreements on S\&T with other countries (Germany, France, and Japan) under which there was no dedicated central funding available in Canada and the lack of Canadian central S\&T funding to match the partner country funding was causing some difficulties in the relationships. Other countries including China saw these agreements as non-binding, but Canada was concerned that if there were no funding to implement the agreement, they would be abrogating a signed agreement. Since there was no appetite at the Department of Finance to establish dedicated pots of central funding for bilateral S\&T activities, why have another such agreement?

\footnotetext{
${ }^{34}$ Author's personal papers from meetings with the Minister and officials of the Ministry of Water Resources, 1998, 1999.
} 
Therefore, Cabinet decided that Canada should not enter into any further government-to-government S\&T agreements unless there were extenuating circumstances. The Cabinet decision was the touchstone for Canadian governments for decades after, and countries requesting such an agreement always hit a stone wall. Instead, MOSST and the then Department of Foreign Affairs and International Trade facilitated meetings of visiting Chinese delegations with key universities as well as departments and agencies such as Agriculture Canada and the National Research Council. ${ }^{35}$ This strategy, at least in part, explains the early and continuing strength of the research relationship across universities and with those two agencies in particular. Among the top 20 Canadian institutions co-publishing with China in the period 2008-2012 (the last years for which numbers are available), most were universities but \#7 is Agriculture and Agri-Food Canada, and \#14 is the NRC. ${ }^{36}$

The delegations that came from China on broader issues of science and technology were very selfeffacing, emphasizing that they had come to learn from Canadian experience. They were not very forthcoming about what their own ministries were introducing as initiatives, nor were many Canadian officials particularly curious about what was happening in China. It was felt that China still had a lot

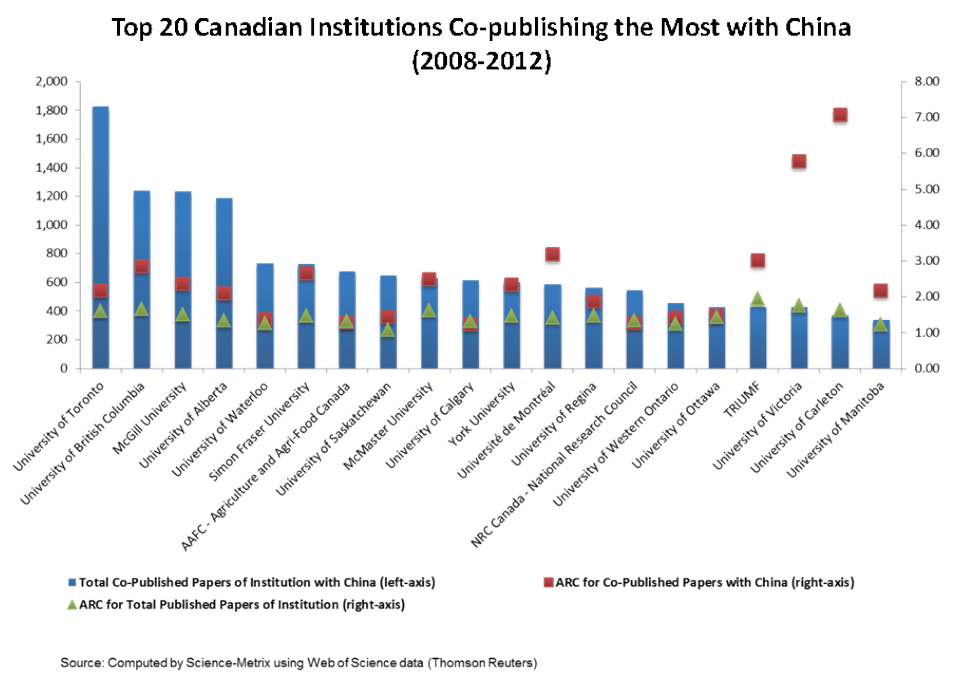

Fig. 4 Top 20 Canadian institutions co-publishing with China

of catching up to do. Presentations and discussion were usually very high level, often with consecutive translation that further detracted from a substantive exchange and cut by half the amount of territory that could be covered in meetings. Throughout these years Canada maintained a network of science and technology counsellors in Canadian Embassies abroad to identify opportunities for collaboration in countries in Europe, Japan, and the United States - but never in China. At its height in the late 1980s there were seven S\&T counsellors and two Space counsellors at posts abroad. However, the crossgovernment budget cuts of the 1990s, designed to reduce the deficit, resulted in a reduction of S\&T

\footnotetext{
${ }^{35}$ Interview August 26, 2014 with David Church, former Deputy Director Science, Technology and Innovation at Department of Foreign Affairs and International Trade.

${ }^{36}$ Computed by Science-Metrix using Web of Science data (Thomson Reuters, 2014) ARC: Average of Relative Citation.
} 
counsellors so that today there are just two - in Washington and Berlin. This impeded the department's ability to engage on S\&T matters with other governments and to support the China S\&T engagement of other stakeholders. There is only now a move to reinforce that function in the department.

China was a member of international organisations such as the Asia Pacific Economic Cooperation (APEC) and the United Nations Educational, Scientific and Cultural Organization (UNESCO), and Canadian officials had opportunities to engage with officials from China in those contexts, including when meetings were hosted in China. ${ }^{37}$ These occasions provided a window through which Canadians could glimpse the state of China's technology development, and brought science and technology best practices together from all over the world, to the benefit of China's organisations.

The real focus of attention for Canada through the late 1980s, 1990s and 2000s was the enormous opportunity for trade. In April 1987, Prime Minister Brian Mulroney's Government quietly announced a China Strategy that had been developed by government officials through extensive consultations with China experts across the country, but according to B. Michael Frolic, it was barely noticed by the Canadian public. The Strategy was focused on improving trade in the "China market" by a "Canada Inc." approach. The text observed that, "China's modern history has been marked by a realization that it cannot become a major power without accepting foreign technology and management techniques, and also by a deeply xenophobic reaction to the penetration of western ideas and philosophy". The Strategy clearly saw the importance of CIDA's role in building on "... China's open-door policy designed to acquire Western technology and skills ... in jointly identified sectors where Canadian expertise meets Chinese priorities, for example, agriculture, energy, and forestry, as well as telecommunications and transportation"; and for the Canadian private sector, "... government support should be directed in a selective fashion to those Canadian companies that have products, technology, and expertise that respond to China's priority requirements, and the 'staying power' to weather both economic 'ups and downs', and the slow approval process" (Cao and Vivienne, 2011). But no one was expecting the reduction of relations that came two years later in 1989. The Strategy was subsumed for a number of years by the Mulroney government, and despite numerous initiatives to have the Cabinets of successive governments approve a new China Strategy or an Asia Strategy, this was the first and also the last public strategy.

But despite the lack of a document laying out a strategic approach, by 1994 the new Prime Minister Jean Chretien was putting a renewed trade focus on China and he began what came to be frequent "Team Canada" missions to China of federal Ministers, business leaders and often provincial Premiers, providing a growing Canada-brand impact over the years. They were very effective in China, with hundreds of trade deals signed and huge goodwill built up. This new warmer relationship was demonstrated at a 1998 Canada/China Business Council dinner of hundreds of Canadian CEOs and university Presidents at the Great Hall of the People where Premier Zhu Rongji departed from his prepared remarks to say that "Canada is our best friend in the whole world! (Evans, 2014)".

That made for a hard act to follow, but when he won the leadership of the Liberal Party in 2003 and became Prime Minister, Paul Martin put a new focus on science, technology and innovation

\footnotetext{
${ }^{37}$ One such example is an Asia-Pacific Economic Cooperation Symposium on High and New Technology and Economy in the $21^{\text {st }}$ Century, Beijing, June 25-27, 1996, co-chaired by the author. Proceedings in the author's personal papers.
} 
broadly, and also gave China high priority in his Government's foreign relations. At that time, the Department of Foreign Affairs and International Trade was developing its policies in relation to the BRIC countries (Brazil, Russia, India and China; later South Africa was added to create BRICS), and was looking for ways in which its international initiatives could contribute to the government's innovation/ commercialisation agenda. A joint Canada-China Strategic Working Group was established to identify ways to enhance collaboration in areas of mutual interest. Prime Minister Martin also appointed Dr. Arthur Carty, then President of the National Research Council, as Canada's first National Science Advisor reporting directly to the Prime Minister, and Carty took the initiative to propose funding for S\&T collaboration with China and India. In the February 2005 Budget, \$20 million over five years was earmarked for international S\&T. The Chinese Embassy presented a draft agreement, but there was a delay until the Canadian government had the policy, mechanism and funding in place.

After a meeting January 20, 2005 in Beijing between Prime Minister Martin and Premier Wen Jiabao, the leaders stated in their Joint Declaration that "Canada and China are committed to strengthening growth and reducing poverty through policies designed to expand trade, investment and innovation in an increasingly integrated global economy" and "we will also strengthen our cooperation through an ambitious program of technical assistance, to support China's full and active participation in the World Trade Organisation". In addition, the statement said that the leaders were resolved to address the problem of global warming in light of their shared commitment to sustainable development and balanced growth. ${ }^{38}$

Later that year, in September 2005 in Ottawa, Prime Minister Martin and President Hu Jintao announced a "strategic partnership" between their two countries. ${ }^{39}$ Under that partnership, they established a Strategic Working Group, still in place fourteen years later, to discuss cross-cutting economic and political priorities. This Working Group brings together the Deputy Ministers of Foreign Affairs, International Trade and Natural Resources (again, an indication of the importance of energy to the relationship), with China's Vice Ministers of Foreign Affairs, Commerce and the National Development and Reform Commission. This is in addition to the annual meetings of the Joint Economic and Trade Commission, a Deputy Minister/Vice-Minister level forum on trade and investment issues. At the September 2005 meeting the leaders in their Declaration on Science and Technology Cooperation struck a high level Canada-China Expert Study Team to advise on "Complementarities in Science and Technology". Co-chaired by senior officials of Canada's National Research Council and China's Ministry of Science and Technology (MOST) and including two academic and industry representatives from each country, the Expert Study Team considered sector priorities and mechanisms for S\&T cooperation.

In October 2005, the Canadian Cabinet approved the terms of the $\$ 20$ million in funding for international S\&T partnerships with China, India, Brazil and Israel under the banner "International S\&T Partnerships Program (ISTPP)". In addition, due to the extenuating circumstances of available funding, Cabinet approved the negotiation of S\&T Agreements with India, China and Brazil and approved the renewal of an S\&T Agreement with Israel.

\footnotetext{
${ }^{38}$ Available at http://english.peopledaily.com.cn/200501/21/eng20050121_171396.html

${ }^{39}$ Photo Credit: Xinhua in SINA English, Hu Jintao meets Canadian Prime Minister Paul Martin, September 11, 2015.
} 
The objectives of the Program were described as:

- encourage domestic competitiveness through the transfer of technology and knowledge resulting from international science and technology partnerships;

- foster international science and technology partnerships and collaborative research;

- accelerate the commercialization of R\&D that would benefit Canada, through international partnerships with a focus on small and medium-sized enterprises;

- access international technologies for Canadian enterprises;

- promote Canadian R\&D capacity and Canada as a destination for foreign technology-based investments; and

- strengthen overall bilateral science and technology relations.

When divided among four countries over five years, \$20 million was a fairly small amount of funding, but it was expected that it would be catalytic, and the collaborations would expand from there. The Department of Foreign Affairs and International Trade (DFAIT) was not equipped to manage a peer review process itself. Therefore, taking as its model a successful S\&T collaboration mechanism with Israel which had been established in 1995 and was looking for a renewal of its funding, Cabinet agreed that the government would fund a new arms-length agency that could implement the peer review process for high priority projects in new and emerging areas of S\&T collaboration. The key issue of ownership of the related intellectual property was to be determined by the project parties prior to the start of each project. In December 2005, the funding was approved in Parliament and the department started the competition process for the organisation to deliver the new program. ${ }^{40}$

In January 2006, Prime Minister Martin's Liberal Party lost a national election to the Conservative Party, and Prime Minister Stephen Harper took office on February 6, 2006. Many noted a cooling of the relationship with China during the first three years of the Harper mandate. The party came to office with a philosophical foundation antithetical communism and cited democracy, religious freedom and human rights among their strongest foreign policy touchstones. As remarked by Paul Evans among others, this moralism led to a China policy built on "cool politics, warm economics". The Prime Minister declined the invitation to attend the 2008 Olympics in Beijing and delayed visiting China until December 2009 when Premier Wen Jiabao reproached him for not visiting earlier. ${ }^{41}$ During this period, Minister of Foreign Affairs Peter McKay and other senior officials stated publicly that they were very concerned about the level of Chinese espionage in Canada, while China's track record on human rights was profiled in the deliberations of a parliamentary sub-committee (Evans, 2014). However, following 2009 there was a recalibration of factors; while these concerns were still very much part of the Government's approach to its broad foreign policy, there was also a more significant focus on the economic and trade lens - particularly in the Conservative Government's Global Commerce Strategy and the Global Markets Action Plan which featured technology and talent as important reasons for partnering with China among others. ${ }^{42}$

\footnotetext{
${ }^{40}$ Interview August 29, 2014 with David Church.

${ }^{41}$ "L'amitie sino-canadiennemise a rude epreuve", La Presse canadienne, Le Devoire December 5, 2009. Available at: http://www. ledevoir.com/politique/canada/278701/1-amitie-sino-canadienne-mise-a-rude-epreuve

${ }^{42}$ Department of Foreign Affairs and Trade, A Global Commerce Strategy for Securing Canada's Growth and Prosperity Available at www.international.gc.ca/commerce/strategy-strategie
} 
Despite the cooling of the relationship in the early years of the Harper Government, the momentum of the Canada-China science and technology discussions carried on and the Expert Study Team for the Complementarities analysis conducted extensive consultations with academic and industry leaders in both countries. The Expert Team reported in 2006, recommending four priority areas for cooperation: energy and environment which they noted as inter-related; and health/life sciences/biotechnology and agriculture foods/bio-products also noted as inter-related. The reasons cited for this selection were current capacities and existing collaborations in both countries, and the degree and nature of economic complementarities. The Expert Team saw areas such as ICT and nanotechnology as enabling other sectors. While they saw the agriculture sector as already having decades of collaboration, they suggested that a new energy subsector such as electric vehicles would require workshops and exchanges to initiate collaboration. The Committee was also clear that the four priority areas should not preclude from future consideration other sectors for potential S\&T cooperation in future. In addition, the Committee recommended that the Government ensure the inclusion of small and medium-sized enterprises (SMEs) in the collaborations, build linkages and partnerships, develop young researchers, and collaborate on joint S\&T infrastructure such as virtual and physical laboratories. Further work was encouraged to address intellectual property challenges and to identify appropriate criteria and mechanisms for measuring progress. ${ }^{43}$ (A broader Canada/ China Economic Complementarities study on trade and investment potential was completed in 2012 and focussed on an industry sector approach rather than covering the areas of the 2006 S\&T Study a second time. $)^{44}$

Also in 2006 the competition for the organisation to deliver on the International S\&T Partnerships Program was completed. The winning group was the agency that until that time had been delivering the agreement with Israel. The President of the new larger arms-length not-for profit organisation decided to adopt the name "International S\&T Partnerships Canada (ISTPCanada)". (Later it was found that there was some understandable confusion on the part of Chinese partners that this nongovernmental organisation delivering a government program by the same name was not itself a government agency.) It was funded by the government to manage the peer-review project selection process, not only for China but also for the Government's agreements with Brazil and India. Israel was being funded by the ISTPP through the Canada-Israel Industrial Research and Development Foundation (CIIRDF). Officials then were able to negotiate agreements quickly with each of China, India and Brazil, and a renewal of the agreement with Israel. ${ }^{45}$

With respect to China, DFAIT and MOST agreed quickly to the terms and conditions. Project proposals would require at least one company and one university in Canada, and one or the other in China. That is a fairly complex requirement to start with for an R\&D proposal, particularly ensuring that intellectual property agreements are clearly established before the project begins. In China, the project review was handled directly by MOST for bilateral cooperation programs such as the one with Canada

\footnotetext{
${ }^{43}$ Canada-China Science and Technology (S\&T) Complementarity Study: A Joint Study on Enhanced Cooperation between Canada and China in S\&T: FINAL REPORT, 2006.

${ }^{44}$ Canada-China Economic Complementarities Study See also the associated press releases accompanying the release of the Study. Available at http://www.international.gc.ca/trade-agreements-accords-commerciaux/agr-acc/china-chine/study-comp-etude.aspx

${ }^{45}$ Interview with David Church, August 26, 2014.
} 
under the Joint Committee. It was a two-stage selection mechanism: the first stage was a strategic review in which an expert panel of MOST reviewed the proposals on target/objectives, tasks and feasibility based on the national strategy, and provided advice as to whether the project should go forward; the second stage was a technical review whereby a different panel reviewed the concrete application proposals and their technical indicators, and provided advice as to its technical feasibility. Then MOST comprehensively considered the review results in the context of the national S\&T development strategy and policy requirements, determined the selected projects, and commissioned relevant agencies to carry out the budget evaluation. MOST reported to the Ministry of Finance on the budget suggestions of the projects based on the budget evaluation results, and the Ministry of Finance normally approved the funding based on the detailed review process, and the projects could then go forward.

For China, the ISTPCanada arms-length (i.e. not government controlled) peer reviewed selection process (modelled on the Canadian granting councils' process) was something they did not favour. Officials of MOST and the Chinese Embassy in Ottawa voiced their objections in pointed, though diplomatic, language. However, DFAIT was firm that this was the process it was going to use; China accepted that. Projects were funded at a Canadian announced amount that covered the Canadian companies and university researchers, and China covered a proportional amount for their own companies and researchers (not necessarily dollar for dollar since costs of the research are often not as high in China).

\section{Canada-China Agreement on Science and Technology}

On January 16, 2007, Canada's Minister of International Trade David Emerson and China's Minister of Science and Technology Xu Guanhua signed the Agreement for scientific and Technological Cooperation Between the Government of Canada and the Government of the People's Republic of China to guide the two countries' science and technology relations for future years. For Canada it was important that this was not just an MOU signed by a single department. Rather, it is one of the only government-wide treaties that Canada has with China, next to the Canada-China Foreign Investment Promotion and Protection Agreement (FIPA) which came into effect October 1, 2014. The S\&T Agreement has been managed through the Department of Foreign Affairs, Trade and Development, now Global Affairs Canada (GAC), and it can coordinate and commit federal departments or agencies. Indeed, some of the earlier departmental MOUs with China have now been brought into conformance by referring to the S\&T Agreement, and future Canadian S\&T-related MOUs will refer to it as well, thereby having the force of a treaty behind the terms that they have signed. For China, it is its $100^{\text {th }}$ intergovernmental science and technology agreement; it is focussed on MOST'S activities, and can link with other Ministries but does not bind them. ${ }^{46}$

The common objectives announced at the time of the signing were: increasing the international competitiveness of our companies; innovation in addressing domestic and global challenges; and

\footnotetext{
${ }^{46}$ Agreement for Scientific and Technological Cooperation between the Government of Canada and the Government of the People's Republic of China, also known as the Framework Agreement for Cooperation on Science, Technology and Innovation. Available at www.treaty-accord.gc.ca/text-texte.aspx?id=105085 Highlights of the Canada-China S\&T Agreement, Committee and funding were included in a presentation on "Canada/China S\&T Relations" by the author September 17, 2013 available at www.ccfso.org/wpcontent/uploads/2014/02/2013-09-17_powerpoint_qiming-Johnston.pdf
} 
commercialisation of technology resulting from R\&D partnerships. To implement the Agreement, the Ministers proposed to establish a funded initiative for bilateral cooperation in science, technology, innovation and commercialisation. The two Ministers also identified the areas of focus which came from the Complementarities Study as mentioned above, and these mapped well with Canada's S\&T Strategy which came out the same year ${ }^{47}$ : life sciences, energy and environment, information and communication technologies. To these sectors, the Ministers added agriculture.

\subsection{Governance}

The Ministers established a Canada-China Joint Committee (CCJC) to steer the decisionmaking on the joint funds and to set priorities for the research. The Co-chair for China has been the Minister and more recently the Vice Minister of MOST. For Canada, the Co-Chair has always been at the Deputy Minister level. For the first three years was the President of the National Research Council; then it was accepted by the President of the Canadian Institutes for Health Research, and it is now held by the Associate Deputy Minister of Innovation, Science and Economic Development Canada. There are six other members of the Committee. At the outset of the Committee, Canada thought it important that its members represent industry (Nortel and then Bombardier), universities (University of Montreal and then University of British Columbia) and government (NRCan and NSERC) ${ }^{48}$ Chinese officials had some concern about having private sector and academic members on the Committee - they usually prefer to work government to government. However, they made a real effort to mirror that model with Deputy Director Generals from appropriate offices of MOST initially, and with representatives such as the Vice President of ZTE Corporation and the Dean of Computer S\&T at Tsinghua University. In 2017 however, the CCJC is underwent a reset. Canadian members were senior government officials, with substantive responsibility for delivering on Canada's innovation agenda.

\subsection{Priority sectors}

Since the first meeting of the Joint Committee May 28, 2007 in Ottawa, seven meetings have been held. The first meeting was focussed on validating the Complementarities Study and establishing the processes and sector groups: agriculture, energy, environment, health/biosciences. In addition, at this first meeting, ICT was added reflecting Canada's S\&T Strategy and this was supported by China (civil aviation was added in 2010). Subsequent meetings reviewed the work programs of each of the sector groups, refined or augmented their focus, and confirmed project areas for calls for proposals. Working groups were put in place for each of the sector areas of priority focus for both governments: clean tech, agriculture, life sciences, and advanced manufacturing. Each is co-chaired by senior officials with sector roles and responsibilities in each country - variously in government or research agencies. On occasion the Committee has been briefed on specific issues or opportunities in S\&T collaboration, such as the

\footnotetext{
${ }^{47}$ Canada's S\&T Strategy announced in 2007 is available at: www.ic.gc.ca/eic/site/icgc.nsf/eng/00871.html

${ }^{48}$ The author was the representative of government science on the Committee, initially in her role as Assistant Deputy Minister Energy Technology at Natural Resources Canada, later as Executive Vice-President of the Natural Sciences and Engineering Research Council. Industry was represented on the Canadian side by the Vice President Technology at Nortel, and then by the VP Technology at Bombardier. The university representative for the first meeting was the Recteur (President) of the University of Montreal, and then the President of the University of British Columbia.
} 
briefings at its 2013 meeting on Mechanisms for Education and Research Institutions as well as a China/ Canada Young Scientists Exchange initiative.

\subsection{Projects}

During the first five years, seventeen projects were selected across all the key sectors: $\$ 4.9$ million for Canadian companies and university researchers, matched on China's side for their companies and university researchers. Projects included:

(1) RoboNurse, was developed, a mechanical device designed to reduce back injuries of nurses by lifting, repositioning and transferring patients - this project involved the Toronto Rehabilitation Institute and two Canadian firms as well as Shanghai Jiaotong University and two Chinese companies.

(2) A more environmentally sound pulp was developed, reducing the cost of making high quality pulp by 90 percent - this project involved the Universities of Toronto and New Brunswick with FPInnovations, a Canadian research institute as well as two Canadian companies, with Tianjin University of Science and Technology and two Chinese companies.

(3) Monitoring Systems for Nuclear Power Plants were developed, identifying a cost-effective wireless communications system to monitor the health and performance of equipment in nuclear plants - the project included Western University, Atomic Energy of Canada Ltd as well as the University of Electronic Science and Technology of China and Chongqing Sichuan Instrument Complex Co. Ltd.

(4) A novel urinary diagnostic kit for acute kidney injury was developed - the project included the University of Alberta and ATGCell Inc as well as Shanghai ChangZheng Hospital.

These are just a few representative examples of the partnerships created. These projects proceeded well and deepened Canada and China's R\&D relations, particularly in industry and academia. One additional dimension facilitated by ISTPCanada was the three-way partnership with Israel in agricultural technologies; the collaboration led to the creation of a trilateral commission with leadership from Canada that brings together officials from the three countries to help cultivate opportunities for mutually beneficial R\&D cooperation. Furthermore, ISTPCanada was contracted to manage a similar peer review process for projects under the $\$ 6$ million Alberta Global Technology Fund.

In addition to the process for the selection of the projects themselves, ISTPCanada conducted 27 partnership activities, such as networking workshops, conferences and symposia for researchers. Sometimes they led to the creation of teams which were ultimately successful in the ISTPP project approvals. A case in point is Professor Ben Tsang at the University of Ottawa. His first Sino-Canada workshop resulted in 40 potential projects in women's reproductive health being identified. In a subsequent request for proposals from a joint CIHR and NSFC program, over four years, the University of Ottawa was successful in 6 of the 12 projects funded (in a success rate of 15\%), and the participants of 11 of the 12 had attended that first Sino-Canada workshop. This is evidence that a small amount of funding can bring people together with substantive research following.

The ISTP Program was progressing well. An early formative program evaluation in 2008 found that it was meeting its objectives, and that ISTPCanada was a cost-effective organisation. Despite the relatively small size of its budget, it had been successful in levering resources from other agencies to supplement its administrative capacity. A summative evaluation in 2010 found that the amount of the financial support was not sufficiently robust to meet the program objectives, and the commercial success was less than expected by the Canadian recipients. Program delays deferred funding 
disbursements but, despite this, the arms-length agency was able to achieve leverage of non-federal funds of 3 to 1 . The evaluation recommended that the department seek a significant increase in the level of funding for the program, and that increased flexibility be sought in the terms and conditions so that the Coordinators of the sector teams would be able to direct programming to specific priority areas, and that the department undertake an assessment of the risks associated with an arms-length agency delivering on partnership relations with other countries. ${ }^{49}$

In November 2011, Prime Minister Harper had a bilateral meeting with President Hu Jintao during the APEC Summit in Honolulu, and the same day he announced renewed support for the ISTP Program that would be used to implement additional projects under the Framework Agreement. In his statement, the Prime Minister said "Canada and China have much to share with one another in the area of science and technology. This support will enable our scientists to work together on innovative new ideas that can be brought to the marketplace to help generate jobs and economic growth".

At the same time, would a number of fairly small projects such as those funded by Canada in the first five years of the program give each country the impact it was looking for? On February 8, 2012, when Prime Minister Harper and Premier Wen Jiabao met in Beijing they announced a decision of the Joint Committee to have a bigger impact by focussing the next competition with more financing on just two areas: energy efficient vehicles (or "clean cars") and human vaccine research at $\$ 4.5 \mathrm{M}$ for Canadian participants in each of these two areas of research, plus the Chinese contribution for their participants. In addition to base funding on the Canadian side, supplementary funding came from within the budgets of the Natural Sciences and Engineering Research Council (NSERC) and the Canadian Institutes for Health Research (CIHR) respectively. This is a model that could be extended in future. In this case, there was a requirement for at least one university and one company from each country. Projects included:

(1) Condition monitoring of powertrain components in electrified vehicles, with McMaster University and D\&V Electronics as well as Beijing Institute of Technology, Shanghai Edrive Co. and Eontronix Co.

(2) Ultra high strength A1 and Mg alloys, hard coatings and their application in engine components, with University of Windsor and Ford Canada as well as CAS Institute of Mechanics and Great Wall Motor Co.

(3) Bioalcohol diesel combustion control for high efficiency and low emission diesel engines with University of Windsor and Ford Canada as well as Shanghai Jiao Tong University and Chang'An Motor Co. and Harbin Dong An Automotive Engine Manufacturing Ltd.

(4) Novel Vaccines for respiratory syncytial virus and parainfluencza virus type 3 with VIDOInterVac and Dalton Pharma Services Inc as well as Guangzhou Institute of Respiratory Disease and South China United Vaccine Institute Ltd.

(5) "Nano-on-micro" delivery system for a vaccine/adjuvant against Helicobacter pylori with University of Western Ontario and PnuVax Inc and Axcelon Biopolymers Inc as well as Chongqing University and Chongqing Jinshan Science and Technology Group Co.

These projects represent excellent research, and it is expected that the partnerships will result in

\footnotetext{
${ }^{49}$ The 2008 and 2010 program evaluations are available on the website of the department at www.international.gc.ca
} 
further collaborations in years to come. In the grander scheme of things, however, these joint projects are small compared to the significant opportunity in China and the pace of developments there. They were designed to start up joint research in areas of emerging importance, which they have certainly accomplished, but Canada felt there was more that could be done. In an effort to broaden the discussion, at the fifth meeting of the Joint Committee, a draft Joint Action Plan was discussed, and it has now been agreed to and signed by both sides. The Action Plan includes concrete actions in each of the Joint Committee's priority sectors. It includes initiatives such as ISO standard development in environmental technology, industrial projects in aerospace, international consortia on genomics, roundtables for biomass and bioenergy transformation, joint research on agri-food production, commercialisation of agriculture technology, and workshops on biofuel transformation and quantum computing. There is a good representation of partners in government, academia and industry from both countries.

\subsection{Challenges}

The Government of Canada recognizes the challenge of engaging China as it accelerates its technology development, and Canada is continuing to give priority to partnering effectively with China to the benefit of Canadian companies and researchers. At the same time, there was recognition that the ISTP Program and the Agreement itself had encountered a few challenges along the way. For example,

(1) For Canada the S\&T Agreement is a treaty and binds departments and agencies. For MOST, it is more akin to an MOU such as it has with many other countries, and it cannot bind other departments. But MOST has been effective in connecting with other agencies where partnerships hold benefits, as can be seen in the various initiatives laid out in the recent Action Plan;

(2) MOST has agreements directly with provincial governments, notably Alberta, British Columbia, Ontario and Quebec, which are increasing the number of partnerships in which it can engage. Canada also has projects and exchanges in China's provinces and at even lower levels of jurisdiction such as municipal S\&T commissions. In order to increase coordination, the Joint Committee has invited provincial representatives to attend as observers at recent meetings, and this will open up that window a little wider;

(3) Canadian university and industry representatives were members of the Joint Committee at the beginning, and the membership on China's side was predominantly from MOST; there has been flexibility shown on the Canadian side to accept the membership that China believes will best support its participation, while China came to accept active members of the Committee from the university and private sectors and at a recent meeting had representation from a university and a company. More recently membership was reviewed again to better align it as a working committee and to provide more continuity from one meeting to the next. Patience and flexibility on both sides have been needed, and is in the best spirit of international partnership;

(4) The contribution agreement process which requires funds to be spent in the year they are booked in the fiscal framework is a practical constraint on the flexibility that one often needs in complex international projects. This became a mounting problem of program administration, and

after detailed review it was decided to bring the program inside the Canadian government, passing responsibility to NRC's Industrial Research Assistance Program, the highly commended program for helping SMEs with R\&D funding and related advice. 
(5) China too had a potential challenge during this period in its own operation of the collaboration. During the three years from 2015 to 2017, massive changes were occurring in China's science and technology programs and governance, whereby more than 100 competed programs providing R\&D funding that had previously been managed within the black box of each Ministry were now to be managed by "arms-length professional executive agencies" with peer review. These changes have been described elsewhere but it is worth noting that, after months of discussion, MOST was successful in persuading the Ministry of Finance that the International Program, with which it partners with Canada and other countries, will be retained within MOST so it can be managed closely as the bilateral conditions with each country require, rather than trying to fit it into one of the five new program areas identified by China's national government.

The Canadian program now called the Canadian International Innovation Program (CIIP) is funding joint collaboration with a number of countries including China (McCuaig-Johnson and Zhang, 2015). As at this writing, three projects in Guangdong Province have been funded, and a broader call for proposals for projects across China has been issued. In addition, missions have been organized on clean tech to Hong Kong and Shenzhen, medical devices and health care to Beijing and Tianjin, and financial technologies to Hong Kong. One important factor as to the impact that the CIIP will have is the amount of funding devoted to it. The entire program funding of $\$ 5 \mathrm{M}$ per year is assigned to competitions for projects in all five countries: China, India, Brazil, South Korea, and Israel. Funding is allocated based on the best projects put forward from whichever countries has the best proposals. Project size is up to $\$ 2.4 \mathrm{M}$, with the Canadian government contribution being $\$ 600 \mathrm{~K}$, the Chinese government contribution the same, plus industry matching contributions from both countries. While MOST is pleased to partner with the CIIP on delivering the program, it is fair to say that it pales in comparison with the targeted funding in Australia, the UK and other western countries that partner actively with China on STI. The experience of the CCJC to date with collaborative projects, combined with the Action Plan going forward, puts Canada and China's government-to-government S\&T relations on a very positive trajectory.

\section{Collaboration in 2018 and Beyond}

The Liberal Government of Prime Minister Justin Trudeau has begun a re-set of Canada's relationship with China. It launched exploratory discussions for a potential negotiation of a Free Trade Agreement. The Prime Minister led an important mission to China in August and September of 2016 that established a strong relationship with President Xi Jinping and announced 56 new commercial agreements worth $\$ 1.2 \mathrm{~B}$ - many involving Canadian technology companies. That visit was returned a few weeks later when Premier Li Keqiang visited Ottawa and Montreal - and four more commercial agreements were announced. Since then, Prime Minister Trudeau visited China again in December 2017. Over this period, there have been many meetings of officials with the purpose to further advance the Canada-China relationship on all fronts including science and technology.

One new area of collaboration is in innovation policy discussions and exchanges. It was decided at the February 2016 meeting of the CCJC that Canada and China would launch an Innovation Dialogue. It was thought that this would add an important policy dimension to the programmatic focus of the Canada/China S\&T relationship to date. China and the US have had an Innovation Dialogue for 
many years, stemming initially from issues that the two countries were finding in trade in technology products. It was led in past on the US side by the White House. Canada's Dialogue is somewhat different - on the Canadian side it is led by officials of ISED, the department responsible for innovation policy, and on China's side by MOST.

The inaugural meeting of the Sino-Canada Innovation Dialogue was held in Beijing on the morning of October 29, 2018. It was co-chaired by Mr Zhang Jianguo, Vice Minister of Ministry of Science and Technology (MOST) and Administrator of State Administration of Foreign Experts Affairs of China (SAFEA), and Mr. David McGovern, Associate Deputy Minister of Innovation, Science and Economic Development Canada (ISED). As a first discussion, officials exchanged information regarding each country's current innovation policies (e.g., Canada's Innovation \& Skills Plan and China's Made in China 2025), best practices and platforms, including superclusters in Canada and high tech parks in China. In addition, the commercialisation of cleantech was discussed. The Dialogue meeting also benefited from presentations by industry leaders who could provide a private sector perspective.

In the afternoon of October 29th, five working group sessions of the Canada-China Joint Committee on S\&T (CCJC) in the priority areas of agricultural-based food and bio-products, health and life sciences, clean technologies, environmental technologies and plastic pollution, and researcher mobility were held.

On October 30, 2018, the CCJC Plenary Session was co-chaired by Mr Zhang and Mr. McGovern. Both sides reported on the progress of the China-Canada Science, Technology and Innovation Action Plan 2016-2018, a collaborative work plan. Likewise, the CCJC reported on initiatives such as Canada's Industrial Research Assistance Program (IRAP) and the successful relaunch of the Canadian International Innovation Program (CIIP). All of these activities have encouraged research collaboration and technological commercialization between the two countries. Co-leads of each sector working group briefed on their collaborative progress and suggestions in the priority areas of agriculturalbased food and bio-products, clean technologies, environmental technologies and plastic pollution, health and life sciences, sub-national collaboration, and researcher mobility.

The co-chairs witnessed the signature of a Cooperative Arrangement between the Department of Agriculture and Agri-food of Canada and the Chinese Academy of Agricultural Sciences of the People's Republic of China on the Canada-China Joint Laboratory for Genetic Improvement and Utilization of Canola/Rapeseed; a Cooperative Arrangement between the Department of Agriculture and Agri-Food of Canada and the Jiangsu Academy of Agricultural Sciences of the People's Republic of China on the Canada-China Joint Laboratory for Genetic Breeding and Integrated Utilization of Legumes; and a Memorandum of Understanding between the National Research Council of Canada and Nankai University of the People's Republic of China Concerning Cooperation in Science and Technology.

Appreciative of the potential for enhanced STI cooperation between the two countries, Associate Deputy Minister McGovern encouraged the CCJC to optimize existing mechanisms while exploring new ones to further increase bilateral engagement. He also invited Canadian and Chinese stakeholders to continue focusing their collaboration initiatives on socio-economic areas such as Cleantech, Agriculture and Agri-Foods, Health and Life Sciences and Researcher Mobility and Environmental Technologies and Plastics. In this context, he summarized the CCJC's goals through key themes, including partnerships, innovation translation and human capacity building. 
Vice Minister Zhang concluded that both sides should enhance personnel exchanges between governmental bodies and scientific communities, support practical collaboration with the use of current resources and the exploration of possible new mechanisms, and encourage the establishment of long and sustained partnerships between local governments, universities and research institutes from both countries. Both sides recognized the outcomes achieved through this meeting, and agreed to hold the $8^{\text {th }}$ CCJC meeting in Canada at a mutually accepted date.

Canadian officials, business leaders, and researchers all need to be aware that the new China under President Xi Jinping has spent the past five years reforming the country's S\&T governance and programs to bring them up to advanced standards of arms-length decision-making and peer review (McCuaigJohnston and Zhang, 2015b). Very often it will be these new programs that will be funding the Chinese side of a joint partnership with Canadian companies and researchers. A series of detailed STI strategies with explicit instructions for implementation have been provided as top-down direction for SOEs, other companies, and university researchers - all designed to bring China up to and then move past other countries' competitive technology positions. ${ }^{50}$ Many billions of dollars are being devoted to:

- developing China's own scientists and engineers, and attracting talent from western countries, for China's research efforts;

- building world-class science facilities with top-of-the-line research equipment;

- mergers and acquisitions to buy all or majority control of technology companies around the world;

- joint ventures to bring Western technology into the Chinese market under a Chinese-controlled corporate entity; and

- lead and influence international technology standards in a wide range of sectors.

China has set aggressive targets for international leadership in science and technology, and is expected to meet those targets. ${ }^{51}$

We are no longer in the 1980s and 90s when China wanted to learn from Western countries and was absorbing any wisdom they could get from Canadian researchers, government officials and companies. China is now leading the development of advanced research and new technologies. Canada has much it can gain from following these trends and partnering with China wherever possible. For example, China now has world-class Big Science projects such as the massive Shanghai Synchrotron and the newly built Jinping Neutrino Observatory. Canadian researchers can bring the latest Western insights to these projects based on decades of international experience in Big Science, including our own Nobel Prize winning facilities such as the Sudbury Neutrino Observatory. Where Canadians have already developed strong research relationships with Chinese researchers over years, this will be much easier to accomplish. And this also applies to researchers in many other science disciplines where China is investing in world-class equipment and facilities.

The same principle applies to Canada's technology companies - there are sectors and technologies where China has research that is leading the world, particularly in advanced technologies such as genomics, artificial intelligence and the Internet of Things. China is making huge investments in these

\footnotetext{
${ }^{50}$ These strategic policy documents are itemized earlier in this paper.

${ }^{51}$ Targets are laid out in each of the Strategies and Plan documents, most notably in the Plan for Implementing the National Strategy of Innovation-Driven Development.
} 
and other research disciplines. Its plans are described clearly in magnificent detail in policy documents such as the Five Year Plan for STI, the Strategy for Innovation-Driven Development, Made in China 2025, the Artificial Intelligence Strategy, and numerous State Council "Opinions" directives (which are similar to Canadian Cabinet Decisions). ${ }^{52}$ Canadian researchers and companies are familiarizing themselves with these strategies to identify where they can best contribute to China's plans and strategies - and then developing a strategy for how to collaborate with these initiatives. Certainly other countries' governments, companies and researchers are also doing these assessments. Canada will need to "get with the program" and see where its own technology needs can be advanced in future by partnering with China.

This takes us back to xin or trust that was discussed at the outset of this paper. With the huge resources of SOEs, Chinese technology companies, and well-funded researchers, there have been, in the past few years, concerns raised about how intellectual property and company collaborations are being managed. While the Chinese government has made significant efforts to address the concerns, Canadian companies need to be assured that their dealings with Chinese partners will be protected and dealt with in the same way as our companies' IP and commercial enterprises are protected through the administrative and judicial systems in other countries. This is not a revolutionary concept. It is the way things work in most other countries around the world. While major progress has been made with designated IP courts in which Western firms are often winning their cases, measures are still needed to ensure that compensation is provided to the firms when the courts determine that payment is to be made - this part of the process is still lagging in the experience of Western firms.

With the Indigenous Innovation Policy and China's strategies and plans, we are on notice that China is looking out for China and wants to partner where it will benefit their country. That's understandable, but combined with the thickening of China's Firewall, it suggests that China is becoming more inward focussed, while still wanting to absorb the advantages of Western technology. This is a real challenge for Canada going forward. Is xin really the ruling principle now - working with partners to advance mutual benefits, or are Chinese companies out to gain advantage over their partners wherever they can on behalf of their nation? Certainly some of the challenges that Western firms have experienced in their joint ventures in China have been shared by Canadian companies. Canada has to navigate a new path with a partner intent on leading the world, while collaborating with China there is clearly mutual benefit. A renewed focus on xin would go a long way toward smoothing the path for a truly two way exchange of knowledge and deeper collaboration.

As this paper demonstrates, there has already been a high level of engagement between Canada and China in industry sectors, government to government, and through joint research initiatives and academic exchanges. All of these are expected to continue and in some areas to accelerate. China has resources to bring to the table to match whatever its bilateral partners provide. The question is, with which of many countries will it partner? Given the importance of China as an economic powerhouse and an emerging innovation leader, Canadian companies and researchers want to be well

\footnotetext{
${ }^{52}$ Plan for Implementing the National Strategy of Innovation-Driven Development, May 2016 and The $13^{\text {th }}$ Five-year National Plan for Science, Technology and Innovation of the People's Republic of China, August 2016. Both promulgated by the Central Committee of the Communist Party of China and the State Council. CPC Central Committee and State Council, Opinions on Deepening the Reform of the Scientific and Technological System and Speeding up the Building of a National Innovation System, September 23, 2013 , p. 6.
} 
positioned to be those partners. The Government of Canada has made a start with the CIIP for funding targeted technologies. A ramp up of the program could position Canada to engage with China more proactively and at a higher level of collaboration. This would clearly benefit Canadian companies as well as researchers in both universities and colleges.

In the coming years, we will want to identify not just where Canada has strengths that can help Chinese partners and access its markets - but where China itself has strengths from which Canada can benefit by partnering with China. With the rise of China's economy and its STI expenditures and performance, it is now on par with, and even excelling above, countries in the West in some technology sectors. The historical one way street of transfer of knowledge and technology from Canada to China is becoming a two way street, and both countries will benefit from this mutual collaboration going forward.

\section{References}

Bradshaw, M.H., 1982. China: 7,000 Years of Discovery at the Ontario Science Centre, Canadian Collector, 1982, 17, 51-51.

Cao, H.H., Vivienne, P., 2011. The China Challenge: Sino-Canadian Relations in the 21st Century, University of Ottawa Press, Ottawa.

Chen, Y., 2012. Driving economic growth with S\&T development - Overview of Canada's S\&T Developments, Global Science, Technology and Economy Outlook 5, 40-46.

Chin, G.T., Frolic, B.M., 2007. Emerging Donors in International Development Assistance: The China Case, IDRC Publications, Ottawa.

Council of Canadian Academies, 2013. Paradox Lost: Explaining Canada's Research Strength and Innovation Weakness, CCA Publications, Ottawa.

Endicott, J.G., 1980. Rebel out of China, University of Toronto Press, Toronto.

Evans, P., 2014. Engaging China: Myth, Aspiration and Strategy in Canadian Policy from Trudeau to Harper, University of Toronto Press, Toronto.

Frolic, B.M., 1996. Everybody Benefits: Canada's Decision to Establish a CIDA China Aid Programme in 1981, York University, June 1996.

Jiang, W.R., 2010. The Dragon Returns: Canada in China's Quest for Energy Security, Asia-Pacific Foundation of Canada and Canadian International Council, Vancouver.

Lieberthal, K., Wang, J.S., 2012. Addressing U.S.-China Strategic Distrust, Brookings Institution, John Thornton China Centre, Washington D.C.

McCuaig-Johnston, M., 2012. Canadian Innovation in Support of Research \& Scholarship, Canada-China Academic Forum, Chengdu, 4 August 2012.

McCuaig-Johnston, M., Zhang, M.X., 2015a. China Innovation incubators: platforms for Partnerships, Asia Pacific Foundation of Canada, Canada.

McCuaig-Johnston, M., Zhang, M.X., 2015b. China Embarks on Major Changes in Science and Technology, Occasional Paper Series China Institute, University of Alberta, Edmonton.

Montreal Neurological Institute and Hospital, 2017, Overview of Historical Relations and Collaborative Projects in China, Montreal, McGill.

Needham, J., 1954. Science and Civilisation in China, Cambridge University Press, Cambridge.

Penner, D., 2016. Ballard Power Systems signs fuel cell factory deal with China, Vancouver Sun, 18 July 2016.

Simon, D.F., Cao, C., 2009. China's Emerging Technological Edge: Assessing the Role of High-End Talent, Cambridge University Press, Cambridge.

Snow, E., 1971. The Long Revolution, Vintage Books, Random House, New York.

Suttmeier, R.P., 1980. Science, Technology and China's Drive for Modernization, Hoover Institution Press, Stanford.

Trudeau, P., Hebert, J., 1961. Two Innocents in Red China, Douglas \& McIntyre, Vancouver, Canada. 
Vanderclippe, N., Praet, N.V., 2017. How China built a global rail behemoth that's leaving Western train makers behind, The Globe and Mail, 9 June 2017.

Wang, Q.M., 2013. Searching for a New Source of Growth: China's Innovation Driven Development Strategy, Joint presentation with Margaret McCuaig-Johnston at the Canada/China Friendship Society, 17 September 2013.

Wilson, J.T., 1959. One Chinese Moon McCorquodale and Blades. Biographical information available at www.britannica. com/EBchecked/topic/644706/J-Tuzo-Wilson.

Wilson, J., 2001. A History of CIDA's China Program, CIDA China Program, Asia Branch, Ottawa.

Zha, Q., 2012. Canadian-Chinese Educational Relationship: Looking Back, Around, and Beyond, Education Matters. 1 May 2012.

Zhan, H.Q., Oldham, G., 2000. An Assessment of Twenty Years of Research Collaboration between China and the IDRC, IDRC Publications, Ottawa. 